\title{
The Impact of Accounting Conservatism on Corporate Performance Indicators in Egypt
}

\author{
Hanaa A. El-Habashy ${ }^{1}$ \\ ${ }^{1}$ Accounting Department, Faculty of Commerce, Menoufia University, Egypt \\ Correspondence: Hanaa El-Habashy, Menoufia University, Egypt. E-mail: hanaa82@hotmail.com
}

Received: July 7, 2019

Accepted: August 10, 2019

Online Published: September 5, 2019

doi:10.5539/ijbm.v14n10p1

URL: https://doi.org/10.5539/ijbm.v14n10p1

\begin{abstract}
This study aims to investigate the impact of conservative accounting on corporate performance indicators of Egyptian firms. A sample of balanced data for the 40 most active non-financial companies was collected in the period 2009-2014 to test hypotheses. Panel regression models were used for data analysis. Givoly \& Hayn (2000) indicator is used as a benchmark for measuring accounting conservatism. The corporate performance indicators used in this study are return-on-assets (ROA) and return on equity (ROE) representing accounting performance measures, as well as Tobin's Q which measures market performance. The results of the research show that accounting conservatism has a significant positive impact on corporate performance indicators. This reflects the positive effect of corporate performance on shareholders that leads to a strong corporate financial position. To the best of our knowledge, no study has been conducted in Egypt as an emerging economy.
\end{abstract}

Keywords: accounting conservatism, Egypt, corporate performance

\section{Introduction}

Accounting conservatism is considered the established financial reporting rules and practices that require prudence by companies to deal with uncertainties and risky conditions (FASB, 1980, IASC, 1989). It restricts the managers' opportunistic behavior to guarantee the shareholders' interests and enhances corporate value. It also affects accounting information which is reflected in investors' decisions, leading to an increase in studies related to accounting conservatism. According to the positive accounting theory, accounting conservatism is an effective contracting and governance mechanism to reduce information asymmetry and resolve agency conflicts (Watt, 2003). Conservatism is a significant accounting constraint that has a substantial impact on the financial reporting process, particularly in choosing accounting policies that are consistent with the conservative approach. Enhancing conservatism practice in financial reporting is a debatable issue in contemporary accounting and has been a major focus in accounting literature. The existing literature indicates that accounting conservatism has a positive impact on a company's economic profit (Sana'a, 2016), contribute to better ethical hazard issues and minimize problems resulting from information asymmetries (García Lara et al. 2016) and facilitate in estimating the future cash flows (Ramadan 2015). These impacts are assumed to enhance the firm's value by improving investment decisions (Lambert et al. 2007). Watts (2003) argues that the accounting conservatism principle remains critical to improving financial reporting.

\subsection{Significance of the Study}

While the relationship between performance and accounting conservatism has been the theme of intensive research in developed and developing economies, no such studies have been conducted in Egypt. According to the contingency theory, the relationship between conservative accounting and corporate performance differs according to the diverse institutional environment. Therefore, it is required to study the practice of accounting conservatism and its impact on corporate performance indicators in Egyptian firms.

\subsection{The Objective of the Study}

The study aims to investigate the influence of the level of accounting conservatism on the performance of the Egyptian listed firms. Hence, the study pursues to answer the question of: to what extent does accounting conservatism affect the performance indicators of listed Egyptian firms? As with the prior research, corporate performance indicators used in this study are return-on-assets (ROA) and return on equity (ROE) representing accounting performance measures, as well as Tobin's Q which measures market performance. The approach of 
Givoly and Hayn's (2000) is used to measure the level of accounting conservatism. Balanced data of the 40 most active non-financial firms were utilized during the period 2009-2014 to test the proposed hypotheses.

\subsection{Contribution of the Study}

This research contributes to the literature by recognizing the impact of the accounting conservatism practice on the performance in non-financial Egyptian firms. Each country is distinguished by its environment, economic, legislative and political systems. Therefore, this study provides a practical and theoretical contribution by examining the effect of adopting the conservative approach to the financial reports on the performance of Egyptian firms. Despite the severe criticism conservatism faces because it conflicts with qualitative characteristics of accounting information, it enhances the protection of shareholders, creditors, and stakeholders in the organization. The impact of accounting conservatism on corporate performance indicators and their impact on earnings and share market value are essential in the corporate financial reporting process. The results are likely to present significant implications for researchers, investors, policymakers, and corporate directors.

The remainder of the paper is organized as follows. The next section discusses the related literature to develop the hypotheses. The research method is explained in detail followed by the empirical results. The conclusions, recommendations, and limitations are in the last section.

\section{Theoretical Background and Hypothesis Development}

\subsection{Conservatism}

Accounting conservatism is the well-established financial reporting rules and practices which require prudence by companies to deal with uncertainties and risky conditions (FASB 1980; IASC 1989). Basu, (1997) explains conservative accounting as requiring a higher degree of verification to recognize good news than that required to recognize bad news in earnings. In the context of uncertainties and economic difficulties, conservative accounting is necessary for the financial reporting process. Givoly \& Hayn (2000) defined conservatism as a choice of accounting principles that reduce accumulative reported earnings by delaying revenue recognition and speeding up expense recognition. Watts (2003) defined it as an asymmetry in verifying earnings and losses as earnings required a higher level of verification than losses, thereby reducing the opportunistic behavior of managers. Hendriksen (1982) points out that in conservative aspects, there is more pessimism than optimism in the financial reporting process. Unconditional conservatism is ex-ante and relies on the managers' ability to select conservative accounting choices. Examples include research and development costs, delays in revenue recognition, the use of accelerated depreciation and amortization of assets as well as the immediate loading of intangible asset costs (Beaver \& Ryan, 2005; Ahmed \& Duellman, 2007; García Lara et al., 2009). The other type is conditional conservatism, that is ex-post and depends on expected events which lead to a lower degree of verification of bad news than good news. Conditional conservatism is applied to enhance the efficiency of debt contracts and corporate governance requirements (Beaver \& Ryan, 2005; Watts, 2003). The literature reported that litigation enhances the level of conservative accounting as litigation arises when earnings and net assets are overstated, but not if their value is understated. In addition, litigation costs induce firms to choose conservative accounting to decrease profits when there are high litigation risks (Watts, 2003). It is suggested that political cost causes are consistent with conservative accounting. The political cost hypothesis proposes that firms are more likely to adopt accounting choices that reduce reported earnings to avoid political scrutiny (Watts and Zimmerman, 1978). The taxation explanation has considered the influence on the accounting choice by managers. Corporate taxes rely on reported profits and asymmetric recognition of losses and gains resulting from conservative financial statements. Companies that already make earnings can reduce or delay taxes by decreasing profits using conservative accounting (Watts, 2003). García Lara et al. (2009) found that taxation, regulation, and political cost motives can also promote conditional conservatism. Holthausen \& Watts, (2001) indicate that regulations and disclosure requirements of the securities committees enhance the level of conservative accounting. Although many empirical studies have investigated conservative accounting, the economic demands of conservatism are still under debate. The literature notes that alleviating agency problems, enhancing contractual agreements, reducing litigation costs, good decision making, and reducing information asymmetry are the results of conservative reporting (Ahmed \& Duellman, 2007; Affes \& Sardouk, 2016). Consequently, under situations of uncertainty and economic difficulties, accounting conservatism is required for the financial reporting process.

\subsection{Literature Review and Hypothesis Development}

Accounting conservatism principle has been evaluated by policymakers and regulators in terms of its advantages and disadvantages. For example, FASB (2010) has discarded conservatism from the conceptual framework as 
they believe that the conservative approach can lead to information asymmetries that influence neutrality. Moreover, Penman and Zhang (2002) debate that conservative accounting can lead to subjective resource allocation and decrease the corporate value that affects the pricing of the shares. Despite the deficiencies of conservative accounting, it provides advantages and benefits obtained from conservative accounting practices that may not otherwise be taken into account by policymakers and regulators (Watts, 2003). Conservative accounting produces conservative reports that have an impact on reducing corporate shareholders' equity which reduce the risk associated with overstated earnings. LaFond and Roychowdhury (2008) argue that the separation between corporate ownership and control encourages managers to overstate the company's net worth and earnings for their own interests. However, Basu (1997) reports that accounting conservatism reduces risks associated with this suspicious practice by corporate management. Ahmed \& Duellman (2011) assert that firms that practice conservative accounting will incur relatively low losses in the financial crisis period compared to firms that do not practice it. This is because managers are more likely to be conservative in preparing earnings during times of crisis. Conservative accounting leads to reducing the financing cost, increasing investment returns, and enhancing the corporate cash value (Li 2015). Moreover, some studies suggest that accounting conservatism positively impacts the quality of financial reports (Kordlouie et al., 2014; Penman \& Zhang, 2002; Ugwunta \& Ugwuany, 2019).

Increased interest in conservative accounting may be due to the fact that accounting standards do not cover all areas of accounting. Some fields require manager judgment, thus, the extent of conservative accounting relies on the manager's decisions (Dey et al., 2008). Positive accounting refers to accounting conservatism as a valuable instrument to alleviate agency conflicts (El-Habashy, 2004). Whereas, accounting conservatism is considered an essential tool in restricting managers' compensation plans and an effective tool to alleviate agency conflicts it also has a significant role in reducing information asymmetries (Bushman \& Smith, 2001; Sloan, 2001) which may improve corporate performance. Conservative accounting makes accounting information more impactful and reliable. Ahmed and Duellman (2011) indicate that conservative accounting has a positive relationship with the future cash flows and gross margins. Moreover, Bill et al. (2013) found a significant association between accounting conservatism and firm value, especially in the crisis period in companies that have high information asymmetries.

Biddle et al. (2011), showed a negative association between conservative accounting and operational cash flows. They indicated that conservatism is a risk management tool in the company. Latridis (2011) found that conserved financial reports lead to obtaining contractual loans at the lowest interest rate and it showed unknown earnings for British companies because of accounting conservatism. However, it also indicated that managers may utilize conditional conservatism for their interest. Using data from Colombian firms during 1996-2002, Penman \& Zhang (2002) suggest that firms that practice conservative accounting affect earnings quality, create a confidential or declared provision, and an impact on the declared income and shareholders' expectations about stock returns. They also indicated at investors' misunderstandings about preparing conservative financial statements, so investors should be asked about the quality of their earned income.

Chan et al. (2006) investigated the impact of earnings quality, which focuses on accruals accounting, on future market returns for non-financial firms listed on the London Stock Exchange. They found a negatively significant association between accounting accruals and future equity returns. Wang (2013) suggests a negative relationship between the level of conservative accounting and the operational risk degree. Also, conservatism can be used as a tool for analyzing investment risk and preparing more balanced financial statements. Based on Jones' model of Iranian firms, Bafghi et al. (2014) investigated the impact of earnings management practices on the liquidity of portfolios and stocks in non-financial firms. They found that earnings management practices had a significant negative influence on stock liquidity and it increases the trading cost.

Ugwunta and Ugwuany (2019) examine the relationship between accounting conservatism and performance in Nigerian firms. Data of 12 Nigerian consumer goods firms were used during 2005-2016. A panel regression analysis was used. The net profit margin (NPM) is used as a proxy of firm performance. The results suggest that accounting conservatism has a positive insignificant influence on firm performance. This indicates that Nigerian Consumer Goods firms tend to be less conservative in financial reports that provide low financial reporting quality. Ramalingegowda \& Yu (2018) investigate the relationship between conservative accounting and corporate capital structure adjustments in a sample of 40,571 U.S. listed firms (1972-2011). The continuous independent variables utilized are leverage, ROA, a market-to-book, total assets, depreciation to total assets, fixed assets to total assets, research and development expenditures to total assets, and a marginal tax rate. They indicated that firms with more conservative financial reports adjusted their capital structure more quickly, especially in firms that relied more on external funding. A positive influence of conservatism on adjustment is 
focused on Low leverage firms. It also shows that accounting conservatism plays a significant role in facilitating capital structure adjustments of low leverage firms.

Ademola and Moses (2017) examine the relationship between conservative accounting and shareholder value in Nigerian companies. Multiple regression analysis was used to analyze data from 20 companies for ten years 2006-2015. The result showed a significant positive association between conservative accounting and shareholders' value. This finding indicates that conservatism is an effective governance mechanism to alleviate information asymmetry and agency conflicts.

Aminu and Hassan (2017) investigate the association between accounting conservatism and bank performance in Nigeria. They used the panel regression for analyzing data of 10 banks for 5 years (2012-2016). The ROA is used as a proxy of bank performance. The results showed a significant association between accounting conservatism and bank performance in Nigeria. Conditional accounting conservatism has a positive correlation with the bank's performance while the bank performance in Nigeria is negatively impacted by unconditional accounting. The study suggests that managers of Nigerian banks should use conditional conservatism in financial reporting to mitigate information asymmetry.

Sana'a (2016) investigates the impact of accounting conservatism on financial performance indicators in Jordanian insurance firms. The ROA, EPS, and MV are used as a proxy of performance. Data of 12 Jordanian insurance firms were used for the period (2007-2014). The results showed that accounting conservatism has a significant positive impact on the three performance indicators of the Jordanian insurance companies. The results of the study strengthen the necessity of adopting the appropriate procedures to encourage Jordanian insurance firms to commit to an acceptable conservative accounting level.

Ramadan (2015) determines the variables affecting the earnings quality of manufacturing firms listed on the Amman Stock Exchange. The continuous independent variables utilized are leverage, corporate performance, investment decisions, accounting conservatism, firms size, and cash holding. The OLS cross-sectional regression model was applied to analyze data from 58 firms during the period 2000-2013. The results showed that corporate performance, leverage, and accounting conservatism are significantly positively affecting earnings quality.

Kordlouie et al. (2014) examined the association between accounting conservatism and financial statements quality of 102 companies listed in Tehran Stock Exchange from 2006 to 2010. Using multivariate regression analysis, the results showed a significant positive association between conservative accounting and the quality of financial reporting. Chiraz and Anis (2013) examines the impact of earnings management on the performance of the IPO on the Paris Stock Exchange. Corporate performance is measured on the basis of the ROA, MV, and EPS. They found a significant positive association between earnings management and return on assets and a significantly negative relationship with returns of shares, and there was no significant impact on the market value of the firm.

Hejazi et al. (2012) examined the influence of earnings quality and income smoothing on corporate performance of 96 listed firms in Iran during 1999-2003. The (P/E) ratio is used as a proxy for corporate performance. The study indicated that earnings quality and income smoothing had no influence on corporate performance.

Based on earlier literature and the above arguments, the results are mixed. Some studies indicate that conservatism restricts managers' opportunistic behavior and enhances corporate performance. However, there are studies which criticize conservatism for the potential distortion of information, its negative impacts on resource allocation and on corporate performance. While the relationship between performance and accounting conservatism has been the theme of intensive research in developed and developing economies, for example Ugwunta and Ugwuany (2019) in Nigeria, Sana'a (2016) in Jordan, Chiraz and Anis (2013) in France, Chiraz and Anis (2013) in Iran, and Chan et al. (2006) in the UK, no such studies have been conducted in Egypt. According to the contingency theory, the relationship between conservative accounting and corporate performance differs according to the diverse institutional environment. Therefore, it is required to study the practice of accounting conservatism and its impact on corporate performance indicators in Egyptian firms. The business environment in Egypt has a significant effect on accounting and financial reporting policies. In line with Gray (1988) about the cultural impact on accounting systems in Egypt, accounting and disclosure procedures are likely to be more conservative and less transparent. That is because conservatism is prominent in a country with weak property rights preservation. Accounting conservatism is an alternative policy in the absence of strong corporate governance to reduce agency conflicts. This study is based on Egyptian firms which are committed to the acceptable level of accounting conservatism and affects the indicators of corporate performance. The study assumes a positive association between accounting conservatism and corporate performance. Therefore, the proposed hypothesis is as follows: 
Hypothesis: Accounting conservatism has a positive effect on corporate performance in Egypt.

\section{Research Methodology}

To test the hypothesis, panel regression is used to analyze cross-section data of non-financial firms during the period 2009-2014. This data was the most recent data available at the time of the study. The study employs a descriptive and correlational research design using panel data.

\subsection{Sample and Data Sources}

This study uses balanced panel data from the 40 most active companies in the Egyptian Stock Market provided by the disclosure book (EGX50). The data spans the period from 2009-2014 which was the latest data available at the time of the study. Data of financial firms are not included because these firms are completely different from non-financial firms and some variables may not be comparable between financial and other firms. The choice of firms was based on the availability of data. Balanced data from the 40 most active non-financial firms with 240 firm-year observations were utilized to test the proposed hypothesis. The sample composition is presented in Table 1.

Table 1. Sample and Composition

\begin{tabular}{lcc}
\hline \multicolumn{1}{c}{ Sector } & \# of firms & \% \\
\hline Industrial Goods and Services and Automobiles & 8 & 20 \\
Real Estate & 8 & 20 \\
Construction and Materials & 6 & 15 \\
Personal and Household Products & 4 & 10 \\
Chemicals & 3 & 8 \\
Telecommunications & 3 & 8 \\
Food \& Beverage & 2 & 5 \\
Healthcare and Pharmaceuticals & 2 & 5 \\
Basic Resources & 1 & 3 \\
Oil and Gas & 1 & 3 \\
Technology & 1 & 3 \\
Travel and Leisure & 1 & 3 \\
\hline
\end{tabular}

\subsection{Dependent Variable}

Three ratios to measure corporate performance indicators were calculated, namely Return on Assets (ROA), Return on Equity (ROE), and Tobin's Q. While the ROE and ROA represent accounting performance measures, Tobin's Q measures the market performance of firms. The study utilizes the data displayed in the financial reports to calculate ROA, ROE and Tobin's Q. Therefore, the main hypotheses can be divided into three sub-hypotheses as follows:

\section{Hypothesis 1: Accounting conservatism has a positive effect on ROA in Egypt. \\ Hypothesis 2: Accounting conservatism has a positive effect on ROE in Egypt. \\ Hypothesis 3: Accounting conservatism has a positive effect on Tobin's $Q$ in Egypt.}

\subsection{Independent and Control Variables}

Accounting conservatism is the independent variable. This study adopts the measurement on the accrual basis suggested by Givoly and Hayn (2000); Ahmed and Duellman (2007) to reflect the accounting accruals in the following period. Accounting conservatism results in negative accruals as the higher the negatives, the higher the level of conservative accounting in corporate financial reporting. Thus, the accounting conservatism approach is:

$$
\begin{gathered}
\text { Accruals }=\frac{\text { EBEXTit }+ \text { DEPit }- \text { OCFit }}{T A} \\
\text { CONACC }=(\text { Accruals }) \times(-1)
\end{gathered}
$$

Where:

CONACC is the accounting conservatism based on the accrual-based measure of conservatism for firm $\mathrm{i}$ in year $\mathrm{t}$, EBEXT is the income before tax and extraordinary items, DEP is the depreciation charge for the year, OCF is 
operating cash flow, and TA is total assets.

Some other factors may also affect a company's performance which must be taken into consideration as control variables. Kayhan and Titman (2007) showed a negative association between performance and leverage. In addition, the literature shows a negative correlation between firm size and performance, as large firms are likely to finance their activities by debt and do not have to choose the accounting method to increase earnings (Dey et al. 2008). The literature argues that the capital adequacy (CA) has a positive influence on performance (Goddard et al. 2004). Codes and measurements of the used variables are summarized in Table 2.

Table 2. Variable Definitions and Measurement

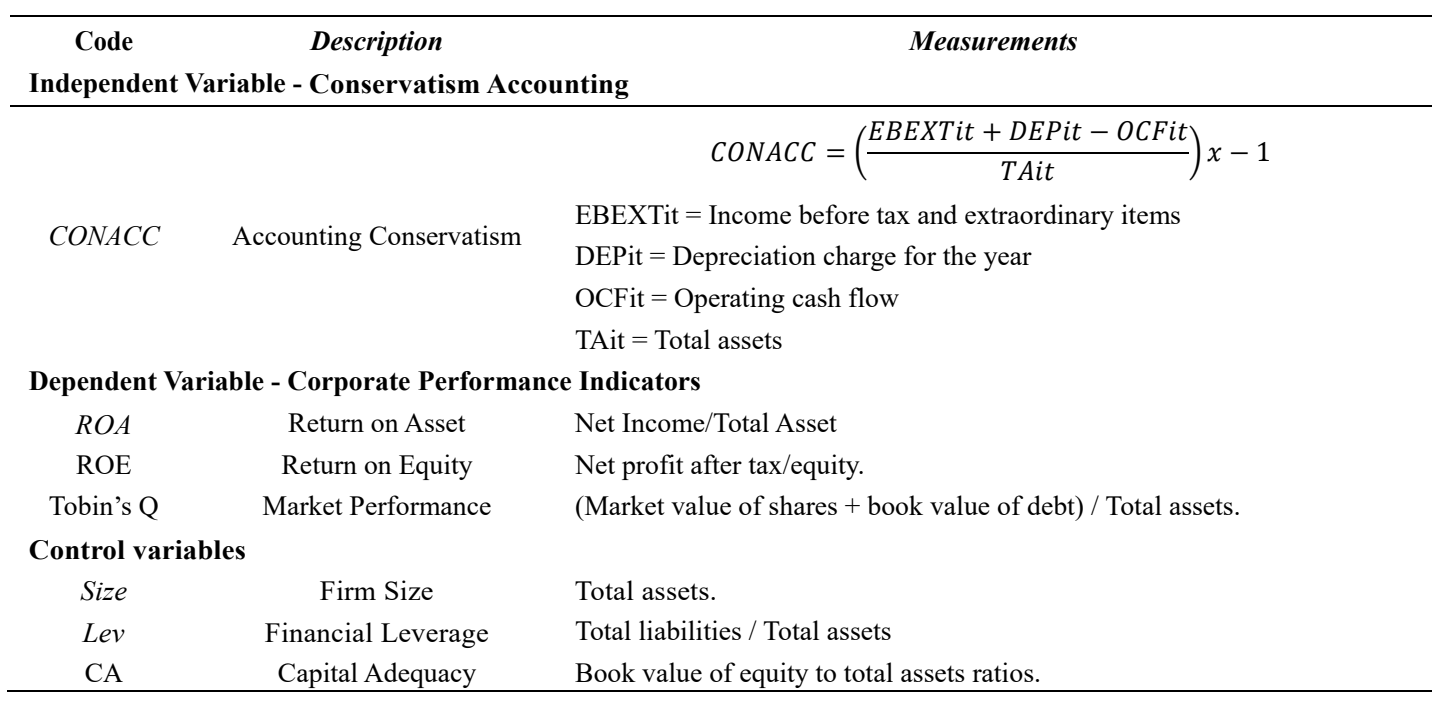

\subsection{Model Specification}

To test the hypotheses, this study estimates three models and employs a fixed effect and random effect panel regression model for the estimation of parameters. The results of the Hausman test are to determine the efficiency of the mentioned methods. Model (1) is formed to test the effect of accounting conservatism on ROA. Control variables are included to determine their influence on return on assets.

$$
\text { ROAit }=\beta 0 \mathrm{i}+\beta 1 \mathrm{CONACCit}+\beta 2 \text { SIZEit }+\beta 3 \mathrm{LEVit}+\beta 4 \mathrm{CAit}+\text { eit }
$$

Model (2) tests the impact of accounting conservatism (CONACC) on (ROE).

$$
\text { ROEit }=\beta 0 i+\beta 1 \text { CONACCit }+\beta 2 \text { SIZEit }+\beta 3 \text { LEVit }+\beta 4 \text { CAit }+ \text { eit }
$$

Model (3) test the impact of accounting conservatism (CONACC) on Tobin's Q.

$$
\text { Tobin's Qit }=\beta 0 \mathrm{i}+\beta 1 \text { CONACCit }+\beta 2 \text { SIZEit }+\beta 3 \text { LEVit }+\beta 4 \text { CAit }+ \text { eit }
$$

Table 3. Descriptive Statistics

\begin{tabular}{cccccc}
\hline & Mean & Median & Std. Deviation & Minimum & Maximum \\
\hline \multicolumn{2}{l}{ Panel A: Dependent variables } & & & & \\
ROA & 0.08 & 0.06 & 0.09 & -0.10 & 0.44 \\
ROE & 0.14 & 0.12 & 0.15 & -0.11 & 0.68 \\
TabinsQ & 0.01 & 0.01 & 0.01 & 0.00 & 0.05 \\
Panel B: Independent and control variables & & & & \\
CONACC & -.073 & -.070 & -.0829 & .144 & -.429 \\
Size & 8049 & 2053 & 14454 & 48 & 59300 \\
Lev & .40 & 0.39 & .24 & .04 & 0.9 \\
CA & 0.01 & 0.01 & 0.00 & 0.00 & 0.04 \\
\hline
\end{tabular}




\section{Statistical Results}

\subsection{Descriptive Statistics}

Table (3) shows that the average accounting conservatism (CONACC) is -.073 . The negative value shows the firms' tendency to be more conservative in financial reports is consistent with Gray (1988). Regarding accounting performance, ROA ranges from $-10 \%$ to $44 \%$ with a mean of $8 \%$ and ROE ranges from $-11 \%$ to $68 \%$ with a mean of $14 \%$. Furthermore, Tobin's Q spans from $0 \%$ to $5 \%$ with a mean of $1 \%$. Regarding control variables, the table shows that firm size ranges from 48 million to about 59 billion with a mean of 8 billion Egyptian pounds.

\subsection{Correlation}

The correlation coefficients are presented in Table (4). Coefficients are shown above and the p-values below. A positive significant correlation was shown between performance indicators, (ROA, ROE, and Tobins'Q) with accounting conservatism (Coef. $=0.409,-0.287, \& 0.264$ respectively) at the $1 \%$ level. The correlation initially supports the research hypothesis. For control variables, ROA is significantly negatively correlated with firm size at the $1 \%$ level. Furthermore, Tobins'Q has a positive effect on financial leverage at the $5 \%$ level and has a negative effect on capital adequacy at the $1 \%$ level (Coef. $=0.129 \&-0.198$ respectively). This means that large-leveraged firms are likely to have good market performance.

Table 4. Pearson Correlation Matrix

\begin{tabular}{|c|c|c|c|c|c|c|c|}
\hline & $R O A$ & $R O E$ & Tobins ' $Q$ & CONACC & Size & Lev & $C A$ \\
\hline$R O A$ & 1 & & & & & & \\
\hline$R O E$ & $\begin{array}{l}.746^{* *} \\
.000\end{array}$ & 1 & & & & & \\
\hline Tobins' $Q$ & $\begin{array}{c}.476^{* *} \\
.000\end{array}$ & $\begin{array}{c}.643^{* *} \\
.000\end{array}$ & 1 & & & & \\
\hline CONACC & $\begin{array}{c}.409^{* *} \\
.000\end{array}$ & $\begin{array}{c}.287 * * \\
.000\end{array}$ & $\begin{array}{c}.264^{* *} \\
.000\end{array}$ & 1 & & & \\
\hline Size & $\begin{array}{c}-.166^{*} \\
.010\end{array}$ & $\begin{array}{l}-.111 \\
.085\end{array}$ & $\begin{array}{l}-.099 \\
.125\end{array}$ & $\begin{array}{l}-.022 \\
.730\end{array}$ & 1 & & \\
\hline Lev & $\begin{array}{l}.102 \\
.115\end{array}$ & $\begin{array}{l}.124 \\
.056\end{array}$ & $\begin{array}{l}.129^{*} \\
.046\end{array}$ & $\begin{array}{l}.598^{* *} \\
.000\end{array}$ & $\begin{array}{l}.133^{*} \\
.039\end{array}$ & 1 & \\
\hline$C A$ & $\begin{array}{l}.083 \\
.198\end{array}$ & $\begin{array}{l}-.107 \\
.098\end{array}$ & $\begin{array}{c}-.198^{* *} \\
.002\end{array}$ & $\begin{array}{l}-.121 \\
.061\end{array}$ & $\begin{array}{c}-.181 * * \\
.005\end{array}$ & $\begin{array}{c}-.351^{* *} \\
.000\end{array}$ & 1 \\
\hline
\end{tabular}

\subsection{Regression Analysis and Discussion}

Tolerance values for each variable are obtained using 1-R2, all values are over 0.10 thus, no multi-collinearity risk exists between the independent variables (see table 5). Furthermore, the VIF value is less than 10 indicating that there is no multi-colinearity between these variables.

Table 5. Collinearity statistics

\begin{tabular}{ccccc}
\hline & CONACC & Size & Lev & CA \\
\hline Tolerance & 0.625 & 0.949 & 0.555 & 0.85 \\
$\quad$ VIF & 1.599 & 1.053 & 1.803 & 1.176 \\
\hline
\end{tabular}

The panel regression results are displayed in the table 6 . The results indicate that accounting conservatism (CONACC) has a significant positive influence on return on assets (ROA). This suggests that $21.9 \%$ of the variance in ROA may be explained by conservative accounting and control factors. The value of $\mathrm{F}$ is 16.435 at the $1 \%$ level that indicates acceptance of the first regression model. The influence of conservative accounting on ROA in model 1 was $(t=3.44)$ highly significant at the $1 \%$ level which demonstrates a conservative accounting approach in the Egyptian firms may positively affect the ROA. Therefore, H1 is accepted. This result is 
consistent with the study of Ramalingegowda \& Yu (2018) and Sana'a (2016) as they found that accounting conservatism has a significant impact on returns on assets. However, it disagreed with Chiraz \& Anis (2013) because they found that earnings management had a significant positive impact on ROA. As expected, there is a negative correlation between firm size and ROA at the level 10\%, as large Egyptian firms are likely to finance their activities by debt and do not have to choose the accounting method to increase earnings (Dey et al. 2008). In addition, the high financial leverage enhances the ROA at the $1 \%$ level. This result supports the debt contracts hypothesis.

Table 6 also suggests that $10.8 \%$ of the variance in ROE may be explained by accounting and control variables. The value of $\mathrm{F}$ is 7.116 at the $1 \%$ level that indicates acceptance of the estimated regression model. The influence in the second model was $(\mathrm{t}=2.47)$ highly significant at the $1 \%$ level which indicates a positive impact of accounting conservatism on ROE. Consequently, enhancing the accounting conservatism in Egyptian firms will positively improve ROE. Therefore, H2 is accepted. This result is consistent with Sana'a, (2016) and Chan et al. (2006) Which showed that conservative accounting significantly positively affects shareholders' expectations on equity returns. It also supports the findings of Chiraz \& Anis (2013) which found that earnings management had a significant negative impact on corporate equity's return.

Table 6. Regression results

\begin{tabular}{|c|c|c|c|c|}
\hline \multicolumn{5}{|c|}{ Panel A: Model (1): ROAit $=\beta 0 i+\beta 1 C O N A C C i t+\beta 2$ SIZEit $+\beta 3$ LEVit $+\beta 4 C A i t+e i t$} \\
\hline $\mathrm{ROA}$ & Coef. & Std. Err. & $t$ & $P$-value \\
\hline cons & 2.933 & 1.484 & 1.98 & 0.048 \\
\hline CONACC & 12,253 & 3,56 & 3.44 & 0.001 \\
\hline Size & 0.000 & 0.000 & -1.68 & 0.092 \\
\hline Lev & 10.041 & 1.221 & 8.22 & 0.000 \\
\hline$C A$ & 0.761 & 0.556 & 1.37 & 0.171 \\
\hline \multirow{2}{*}{ Model Summary } & R-squared & Adj R-squared & $\mathrm{F}$ & P-Value \\
\hline & 0.219 & 0.205 & 16.435 & 0.000 \\
\hline \multicolumn{5}{|c|}{ Panel B: Model (2): $R O E i t=\beta 0 i+\beta 1 C O N A C C i t+\beta 2$ SIZEit $+\beta 3 L E V i t+\beta 4 C A i t+e i t$} \\
\hline ROE & Coef. & Std. Err. & $t$ & P-value \\
\hline cons & 13.72 & 2.59 & 5.3 & 0.000 \\
\hline CONACC & 23.34 & 9.44 & 2.47 & 0.013 \\
\hline Size & 0.000 & 0.000 & -0.64 & 0.524 \\
\hline Lev & -1.58 & 3.18 & -0.5 & 0.618 \\
\hline$C A$ & -0.54 & 1.52 & -0.36 & 0.721 \\
\hline \multirow{2}{*}{ Model Summary } & R-squared & Adj R-squared & $\mathrm{F}$ & P-Value \\
\hline & 0.108 & 0.093 & 7.116 & 0.000 \\
\hline \multicolumn{5}{|c|}{ Panel C: Model (3): Tobin's Qit $=\beta 0 i+\beta 1 C O N A C C i t+\beta 2 S I Z E i t+\beta 3 L E V i t+\beta 4 C A i t+e i t$} \\
\hline Tobins'Q & Coef. & Std. Err. & $t$ & P-value \\
\hline _cons & 1.558 & 0.15 & 10.37 & 0.000 \\
\hline CONACC & 1.578 & 0.608 & 2.59 & 0.009 \\
\hline Size & 0.000 & 0.000 & -1.873 & 0.062 \\
\hline Lev & -0.069 & 0.203 & -0.395 & 0.164 \\
\hline$C A$ & -0.191 & 0.997 & -1.92 & 0.055 \\
\hline \multirow{2}{*}{ Model Summary } & R-squared & Adj R-squared & $\mathrm{F}$ & P-Value \\
\hline & 0.121 & 0.106 & 8.801 & 0.000 \\
\hline
\end{tabular}

In addition, the results show a statistically significant impact on market performance (Tobin's' Q) model. The findings suggest that $12.1 \%$ of the variance in the market performance (Tobins'Q) may be explained by the variation in accounting conservatism and the control variables. The value of $F$ is 8.801 at the $1 \%$ level that indicates acceptance of the third regression model. The influence in the third model was $(\mathrm{t}=2.95)$ significant at the $1 \%$ level. It suggests that conservatism has a positive impact on market share value as enhancing accounting conservatism will positively increase the market share value in Egyptian firms. Consequently, H3 is accepted. 
This result supports Sana'a, (2016) which reports that accounting conservatism has a significant positive impact on market share value, and opposed Chiraz \& Anis (2013) which detected an insignificant impact of earnings management on firm's market value.

The results show that the leverage level of a company does not affect RAE and Tobin's' Q. This result opposes the debt contracts hypothesis which indicates that income-increasing accounting choices are positively associated with leverage (Dey et al. 2008). Consistent with the literature, firm size has a significant negative impact on ROA and Tobin's' $\mathrm{Q}$ at the level of $10 \%$. This result supports the political cost as large firms do not have to choose the accounting method that increases earnings (Dey et al. 2008). The results indicate that the capital adequacy of a company does not affect corporate performance, which is inconsistent with Goddard et al. (2004) that expect a positive influence on performance.

\section{Conclusions and Recommendations}

This study aims to examine the impact of accounting conservatism on corporate performance indicators in Egyptian firms. The corporate indicators used in the study are the return on assets (ROA), return on equity (ROE), and Tobin's Q. The results detected that the level of accounting conservatism had a positive impact on performance indicators in Egypt. Indicating that conservative accounting policies reduce the corporation's declared income while cash flows remain constant due to unrecognized earnings. This results in earnings continuity rather than accruals continuity in subsequent years. It also leads to earnings quality that illustrates real earnings and helps predict real earnings in the future. The results reflect the positive effect of corporate performance on shareholders that lead to a strong corporate financial position. It is necessary to attract new investors and enhance the firm's ability to maintain stakeholders and strengthen their confidence in their financial position. The results of this study can provide recommendations to help the companies in improving their performance. The study contributes to the existing literature on the impact of accounting conservatism on corporate performance indicators in Egypt. The high level of accounting conservatism in the financial reporting process enhances corporate performance indicators. Policymakers must compel companies to adopt the appropriate procedures to accept accounting conservatism levels. Another recommendation to the external auditors is to express their opinions on the sufficiency of conservatism level in financial reporting, which are assumed to have a positive impact on corporate performance. Therefore, further research must be undertaken considering more performance indicators and using larger samples and longer time periods to enhance the results of the study.

The study has limitations as the research uses data from only the 40 most active nonfinancial firms listed on the Egyptian Stock Exchange. However, this index is the preferred index for investors in Egypt. Moreover, the data is for period 2009-2014 which was the latest data available at the time of the study. The data of financial firms are excluded as these companies are totally different from non-financial companies, and some attributes may not be comparable between financial and other companies.

\section{References}

Ademola, O. J., \& Moses, O. I. (2017). Accounting Conservatism and its Benefits to Shareholders in Developing Capital Market, Evidence from Nigeria. Journal of Accounting and Finance, 17(1), 89-96.

Affes, H., \& Sardouk, H. (2016). Accounting Conservatism and Corporate Performance: The Moderating Effect of the Board of Directors. Journal of Business \& Financial Affair, 5(2), 1-6. doi: $10.4172 / 2167-0234.1000188$

Ahmed, A. S., \& Duellman, S. (2007). Accounting conservatism and board of director characteristics: an empirical analysis. Journal of Accounting and Economics, 43(2), 411-437. http://dx.doi.org/10.2139/ssrn.887301

Ahmed, A. S., \& Duellman, S. (2011). Evidence on the Role of Accounting Conservatism in Monitoring Managers' Investment Decisions. Accounting, and Finance, 51(3), 609-633. http://dx.doi.org/10.2139/ssrn.1012347

Aminu, L., \& Hassan, S. U. (2017), Accounting Conservatism and Financial Performance of Nigerian Deposit Money Banks: An Analysis of Recent Economic Recession. Scholedge International Journal of Business Policy \& Governance, 4(12), 124-135. http://dx.doi.org/10.19085/journal.sijbpg041201

Bafghi, F. D., MoeinAddin, M., \& Dehnavi, H. D. (2014). The effect of earnings management on the stock liquidity. Interdisciplinary Journal of Contemporary Research in Business, 5(11), 73-81.

Basu, S. (1997). The conservatism principle and the asymmetric timeliness of earnings. Journal of Accounting 
and Economics, 24(1), 3-37. https://doi.org/10.1016/S0165-4101(97)00014-1

Beaver, W., \& Ryan, S. (2005). Conditional and Unconditional Conservatism: Concepts and Modeling. Review of Accounting Studies, 10(2-3), 269-309.

Biddle, G., Ma, M., \& Song, F. (2013). The Risk Management Role of Accounting Conservatism for Operating Cash Flows. The University of Hong Kong. Retrieved from http://hub.hku.hk/bitstream/10722/169281/1/Content.pdf

Bill, F., Iftekhar, H., \& Qiang, W. (2013). The benefits of conservative accounting to shareholders: Evidence from the financial crisis. Accounting Horizons, 27, 319-346. https://doi.org/10.2308/acch-50431

Bushman, R., \& Smith, A. (2001). Financial Accounting Information and Corporate Governance. Journal of Accounting and Economics, 32(1-3), 237-334. https://doi.org/10.1016/S0165-4101(01)00027-1

Chan, K., Chan, K. C., Jegadeesh, N., \& Lakonishok, J. (2006), Earnings Quality and Stock Returns. Journal of Business, 79(3), 1041-1082. Retrieved from https://ssrn.com/abstract=272119

Chiraz, D., \& Anis, J. (2013). Earning Management and Performance of French IPO Companies. Journal of Accounting and Taxation, 5(1), 1-14. https://doi.org/10.5897/JAT2013.0106

Dey, C. R., Grinyer, J. R., Sinclair, C. D., \& El-Habashy, H. (2008). Determinants of accounting choices in Egypt. Journal of Applied Accounting Research, 8(3), 48-92. https://doi.org/10.1108/96754260880001054

El-Habashy, H. (2004). Determinants of accounting choices in Egypt: An empirical study. Doctoral Thesis, University of Dundee, Scotland, UK.

El-Habashy, H. (2019). The Effect of Corporate Governance Attributes on Accounting Conservatism in Egypt. Academy of Accounting and Financial Studies Journal, 23(3), 1-18.

García Lara, J. M., Garcia Osma, B., \& Penalva, F. (2009). Accounting conservatism and corporate governance. Review of Accounting Studies, 14(1), 161-201. https://doi.org/10.1007/s11142-007-9060-1

García Lara, J. M., Garcia Osma, B., \& Penalva, F. (2016). Accounting conservatism and firm investment efficiency. Journal of Accounting and Economics, 61(1), 221-238. https://doi.org/10.1016/j.jacceco.2015.07.003

Givoly, D., \& Hayn, C. (2000). The changing time-series properties of earnings, cash flows, and accruals: has financial reporting become more conservative? Journal of Accounting and Economics, 29(3), 287-320. https://doi.org/10.1016/S0165-4101(00)00024-0

Goddard, J., Molyneux, P., \& Wilson, J. (2004). The profitability of European banks: A cross-sectional and dynamic panel analysis. The Manchester School, 72(3), 363-81. https://doi.org/10.1111/j.1467-9957.2004.00397.x

Gray, S. J. (1988). Towards a Theory of Cultural Influence on the Development of Accounting Systems Internationally. Abacus, 24(1), 1-16.

Hejazi, R., Ansari, Z., Sarikhani, M., \& Ebrahimi, F. (2012). The Impact of Earnings Quality and Income Smoothing on the Performance of Companies Listed in Tehran Stock Exchange. International Journal of Business and Social Science, 2(17), 193-197. https://ssrn.com/abstract=2062110

Hendriksen, E. S. (1982). Accounting Theory ( $4^{\text {th }}$ ed.). Homewood, IL: Richard D Irwin.

Holthausen, R., \& Watts, R. (2001). The relevance of the value-relevance literature for financial accounting standard setting. Journal of Accounting and Economics, 31(1-3), 3-75. https://doi.org/10.1016/S0165-4101(01)00029-5

Kayhan, A., \& Titman, S. (2007). Firms' histories and their capital structures. Journal of Financial Economics, 83(1), 1-32. https://doi.org/10.1016/j.jfineco.2005.10.007

Kordlouie, H., Mohammadi, F., Naghshineh, N., \& Tozandejani, M. (2014). Role of Accounting Conservatism on the Quality of Financial Statements. International Journal of Business and Management, 9(1), 129-139. http://dx.doi.org/10.5539/ijbm.v9n1p129.

LaFond, R., \& Roychowdhury, S. (2008). Managerial ownership and accounting conservatism. Journal of Accounting Research, 46(1), 101-135. http://dx.doi.org/10.2139/ssrn.929693

Lambert, R., Leuz, C., \& Verrecchia, R. E. (2007). Accounting Information, Disclosure, and the Cost of Capital. Journal of Accounting Research, 45(2), 385-420. https://doi.org/10.1111/j.1475-679X.2007.00238.x 
Latridis, G. (2011). Accounting disclosures, accounting quality, and conditional and unconditional conservatism. International Review of Financial Analysis, 20(2), 88-102. https://doi.org/10.1016/j.irfa.2011.02.013

Li, X. (2015). Accounting Conservatism and the Cost of Capital: International Analysis. Journal of Business Finance \& Accounting, 42(5\&6), 555-582. https://doi.org/10.1111/jbfa.12121

Penman, S. H., \& Zhang, X. J. (2002). Accounting conservatism, the quality of earnings, and stock returns. The Accounting Review, 77, 237-264. https://doi.org/10.2308/accr.2002.77.2.237

Ramadan, I. Z. (2015). Earnings quality determinants of the Jordanian manufacturing listed companies. International Journal of Economics and Finance, 7(5), 140-146. https://doi.org/10.5539/ijef.v7n5p140

Ramalingegowda, S., \& Yu, Y. (2018). The Role of Accounting Conservatism in Capital Structure Adjustments. Journal of Accounting, Auditing \& Finance. https://doi.org/10.1177/0148558X18814119

Sana'a, N. M. (2016). The Effect of Accounting Conservatism on Financial Performance Indicators in the Jordanian Insurance Companies. Journal of Internet Banking and Commerce, 21(1), 1-16.

Sloan, R. G. (2001). Financial accounting and corporate governance: A discussion. Journal of Accounting and Economics, 32, 335-347. http://dx.doi.org/10.2139/ssrn.25851

Ugwunta, D. O., \& Ugwuany, B. U. (2019). Accounting Conservatism and Performance of Nigerian Consumer Goods Firms': An Examination of the Role of Accruals. International Journal of Financial Research, 10(1), 1-9. https://doi.org/10.5430/ijfr.v10n1p1

Wang, R. Z (2013). Operating risk and accounting conservatism: an empirical study. The International Journal of Business and Financial Research, 7, 12-29. https://ssrn.com/abstract=2148693

Watts, R. L. (2003). Conservatism in Accounting Part I: Explanations and Implications. Accounting Horizons, 17(3), 207-221. http://dx.doi.org/10.2139/ssrn.414522

Watts, R. L., \& Zimmerman, J. L. (1978). Toward a positive theory of the determination of accounting standards. The Accounting Review, 53, 112-134. https://www.jstor.org/stable/245729

\section{Copyrights}

Copyright for this article is retained by the author(s), with first publication rights granted to the journal.

This is an open-access article distributed under the terms and conditions of the Creative Commons Attribution license (http://creativecommons.org/licenses/by/4.0/). 